\title{
Effect of Lethal and Sub-lethal Concentrations of Tobacco (Nicotiana Tobaccum) Leaf Dust Extract on Weight and Hematological Changes in Clarias Gariepinus (Burchell)
}

\author{
*OMONIYI, I.; AGBON, A O; SODUNKE, S A \\ Department of Aquaculture \& Fisheries Management, University of Agriculiure, P.M.B. 2240, Abeokuta, Nigeria.
}

\begin{abstract}
ABSTRAC'T: Lethal and sub-lethal bioassays on Clarias gariepinus were conducted to evaluate the toxicity of tobacco (Nicotiana tobaccum) leaf dust on weight gain and haematological indices of Clarias gariepinus (mean weight $10.5 \pm 0.70_{\mathrm{g}}$ ) in glass aquaria with acration system. The concentrations used during the gare $2.00,1.00,0.50,0.25 \mathrm{~g} /$ and a control $(0.00 \mathrm{~g} / 1)$; while the concentrations of the toxicant used during the 21 -days sub-lethal exposure were $0.30,0.15,0.10,0.05 \mathrm{~g} / \mathrm{and}$ a control $(0.00 \mathrm{~g} / \mathrm{l})$. The $48-\mathrm{h} \mathrm{LC}_{50}$ estimated by probit analysis during acute exposure was found to be $626.0 \mathrm{mg} / \mathrm{l}$. The results obtained from the subestimaled by probit analysis dung acule exposure decrease in weight of fish as the concentration of the toxicant increased. Also, hacmatological indices indicated that the lish became anaemic and the severity of this condition was directly proportional to the tobaceo dust concentrations. (a) JASEM
\end{abstract}

liish llesh is about the best source of animal protein due to the low level of connective tissue that makes it more digestible than other animal protein source and moreover, it is well documented in the literature that fish is a better source of vitamins (A, B1, B6, D and E) and minerals than meat (Al-Jedah et al, 1999; Egan et $a l, 1981)$. Fish is an alternative cheap source of animal protein in Nigeria, which is sought after by many due to short supply of other animal products as highlighted by Omoniyi (1995). Unfortunately, the average annual supply comprising both domestic production and import of about 750,000 tonnes in 1997 is far below the demand which is estimated at 1.86 million tones annually (Otubusin,1999). Fish production through aquaculture has been identified as a more practical and promising approach to meeting the fish demand, but there are a number of factors militating against the development of culture fisheries. Predatory animals such as chaoborus larvae, tadpoles, frogs, leeches and 'weed' fish species which compete and predate on fry and fingerling of stocked fish constitute one of the problems of the Nigerian fish culturists have to contend with. This aspect of culture management must be addressed if Nigeria is to meet her animal protein demand through fish production. It is a common preliminary practice in fish culture operations to use synthetic toxins including chlorinated hydrocarbons and organophosphates to eradicate these predatory and competing fish from nursery, rearing and production ponds prior to the stocking of preferred commercial fish species. However, the application of synthetic toxins is not advisable due to their toxicity to other non-target aquatic species, persistence in the environment (Mason,1998) and even to the consumers of the fish.

The use of specific natural biocides with pesticide properties, derived from plants, has been reportedly used by some artisanal fishermen in Nigeria (Reed et al, 1967). 'Tobacco plant (Nicotiana tobaccum) leaf is one of such with pesticidal properties. The active ingredient in tobacco leal is nicotine which constitutes $2-5 \%$ dry weight on the leaf (Hassal, 1982). Agbon et al (2002) studied the toxicity effect of tobacco leaf dust extract on $O$. niloticus one of the culturable fish species in Nigeria. No study has yet been reported on the effect of tobacco on Clarias gariepinus, another culturable species, which is very popular because of the price it commands. Therefore, this study is necessary. The effect of toxicants on fish can be assessed by the use of haematological indices as it has been reported to be a routine procedure in toxicological research, environmental monitoring and fish health conditions (Blaxhall, 1972; Smit et al, (1979). Also, Sampath et al (1993) observed that studies on fish blood could reveal conditions within the body of fish long before an outward manifestation of disease condition. This study was therefore conducted to investigate the effect of water extract of tobacco leaf dust on Clarias gariepinus to determining the 48-h $\mathrm{LC}_{50}$ and the effect of sub-lethal concentrations on weight gain and haematological indices.

\section{MATERIALS AND METHODS}

Fingerling (average weight $10.5 \pm 0.7 \mathrm{~g}$ ) of pure $C$. gariepinus were procured from CHI Nigeria Limited, Lagos. They were transported in oxygenated polythene bags to the Department of Aquaculture and Fisheries Management, University of Agriculture, Abeokuta where they were acclimated in out-door glass aquaria for seven days before experimentation. The dried leaves of tobacco (Nicotiana tobaccum) were purchased at a local market in Abeokuta, Ogun State. The leaves were oven-dried to a constant weight at a temperature of $60^{\circ} \mathrm{C}$ in less than 4 hours using a Gallenkamp oven. It was powdered with the

*Corresponding author 
aid of Moulinex electric blender and stored in dry airtight container.

The acclimated fingerlings were randomly allocated to glass aquaria, each with dimension of 60 $\times 30 \times 30 \mathrm{~cm}$. Dechlorinated tap water from storage tank was used and these parameters: temperature, dissolved oxygen, $\mathrm{NH}_{3}$-Ammonium, $\mathrm{pH}$ and conductivity were monitored in each aquarium, with the aid of portable water quality analysis kit. A stock solution of the tobacco leaf extract with a concentration of $25 \mathrm{~g} / \mathrm{l}$ was prepared and test solutions were obtained from it by serial dilutions. The volume of each test solution used in the bioassay per replicate in all treatments was 20litres. The concentrations of the water extract of tobacco dust in each treatment were: $2.0,1.0,0.5$ and $0.25 \mathrm{~g} / \mathrm{l}$. There was also a control. For each treatment, there were two replicates. 10 fish were put into each aquarium for the acute bioassay test, which lasted for 48 hours. Fresh preparations of the test solutions were introduced into the aquarium for toxicity test as described by Buikema et al (1982). During the exposure period, dead fish observed was removed and recorded. The lethal concentration that caused 50\% mortality (48-h $\mathrm{LC}_{50}$ ) was estimated by probit analysis as described by Wardlaw (1985).

The sub-lethal tests were conducted in the aquaria with test solutions of $0.3,0.15,0.10,0.05 \mathrm{~g} / 1$ concentration and a control. Five (5) fish were put into each aquarium and fed $3 \%$ of body weight once a day with a diet of rice-bran and fish meal. The test solutions were changed every three days and the experiment lasted for 21 days. The temperature, $\mathrm{pH}$ and dissolved oxygen were determined with Jenway 3150 dual-purpose meter, conductivity was determined with a TOA model CM-205 conductivity meter while the total ammonia was estimated with TOA model $1 \mathrm{M}-5 \mathrm{~s}$ ion-meter. The initial weights of the fish prior to sublethal exposure and final weights at the end of twenty-one days, were taken with the aid of Mettler balance model PB602.
At the end of 21-days, blood was collected from fish by cardiac puncture with the aid of hypodermic needle and syringe $(2 \mathrm{ml})$, put into EDTA vials and taken to laboratory for analysis using method described by Blaxhall and Daisley (1973). The haematological parameters analysed were Haemoglobin $(\mathrm{Hb})$, packed cell volume (PCV), Red blood count (RBC), mean cell volume (MCV), mean cell haemoglobin $(\mathrm{MCH})$, mean cell haemoglobin concentration $(\mathrm{MCHC})$, total protein and glucose. The values for each treatment concentration were subjected to statistical analysis using a two - way analysis of variance at $5 \%$ level of probability.

\section{RESULTS}

The acute toxicity test showed that all fish in the control medium survived during the experiment while mortalities were observed in all other treatments. The mean mortality in each treatment was converted to percentage mortality that was transformed into percent probit with the aid of probit table (Wardlaw, 1985). The probit mortality curve shown in Figure 1 was subjected to regression analysis and from the trend line the $48 \mathrm{~h} \mathrm{LC}_{50}$ of the tobacco leaf dust extract was estimated to be $0.626 \mathrm{~g} / \mathrm{l}$. The fish were also observed to be restless and jumping in the bioassay media. The frequency of jumping and degree of restlessness were noticed to be high in the bioassays as the concentrations of toxicant increased. The toxicity disappearance time for tobacco leaf dust extract in the highest concentration was found to be five days.

The sub-lethal effect on the weight revealed that as the concentration of the extract increased there was a corresponding decrease in body weight gained by fish during the 21 - days exposure period (Figure 2). The effect of the tobacco dust extract on some haematological parameters of fish shown in Table 1 reveals significant difference $(p<0.05)$ among the treatments except for the mean cell haemoglobin concentration (MCIIC) which showed no differences.

Table 1. Mean values (with standard errors in parentheses) of haematological parameters of Clarias gariepinus exposed to sub lethal concentrations of tobacco leaves extract.

\begin{tabular}{|c|c|c|c|c|c|}
\hline \multirow{2}{*}{$\begin{array}{l}\text { 1 lacmatological } \\
\text { Parameters }\end{array}$} & \multicolumn{5}{|c|}{ Concentration of tobacco leaves extract $(\mathrm{g} / \mathrm{l})$} \\
\hline & Control 0.00 & 0.05 & 0.10 & 0.15 & 0.30 \\
\hline PCV $(\%)$ & $12(1.00)$ & $11.50(0.50)$ & $11.00(2.00)$ & $9.00(1.00)$ & $8.50(1.00)$ \\
\hline $1 \mathrm{lb}(\mathrm{g} / \mathrm{dl})$ & $4.10(0.20)$ & $3.95(0.50)$ & $3.70(0.30)$ & $3.05(0.25)$ & $2.85(0.15)$ \\
\hline RBC(mmision & $1.35(0.05)$ & $1.30(0.10)$ & $1.30(0.20)$ & $1.10(0.20)$ & $0.95(0.05)$ \\
\hline $\operatorname{MCV}\left(1 / \mathrm{m}^{3}\right)$ & $89.50(2.20)$ & $89.50(1.60)$ & $89.50(1.20)$ & $84.50(2.40)$ & $81.50(2.50)$ \\
\hline $\mathrm{MCl} / \mathrm{u} / \mathrm{mg})$ & $30.50(0.50)$ & $30.50(1.30)$ & $30.00(2.10)$ & $28.50(0.80)$ & $28.00(1.60)$ \\
\hline *MCIIC $(1 / 10)$ & $34.50(1.00)$ & $34.50(0.50)$ & $34.00(1.00)$ & $33.50(1.50)$ & $33.50(0.50)$ \\
\hline Total proteis (mg/dl) & $20.00(1.80)$ & $19.50(2.10)$ & $18.00(0.70)$ & $16.50(1.55)$ & $12.00(2.20)$ \\
\hline (jlacose (mg/dl) & $16.00(1.40)$ & $14.00(0.80)$ & $12.50(0.50)$ & $11.00(1.10)$ & $9.50(0.30)$ \\
\hline
\end{tabular}

* No significant difference. 


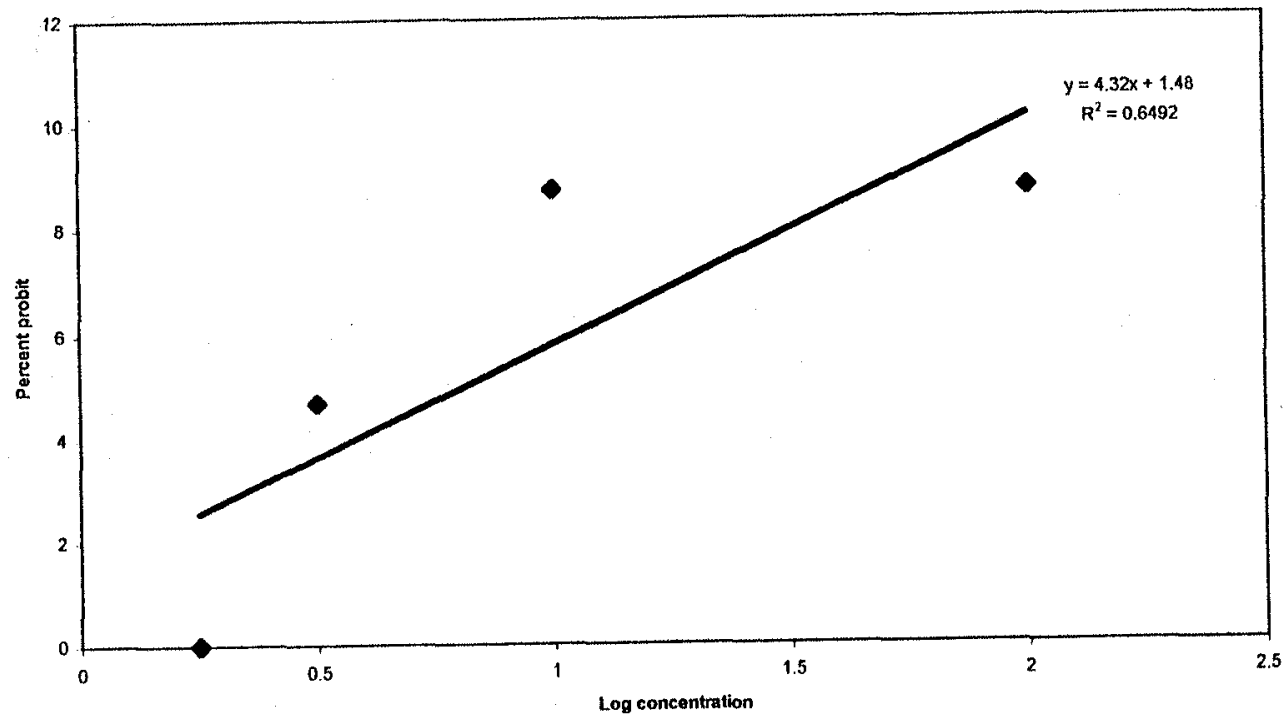

Figure 1. Probit mortality curve of C. gariepinus

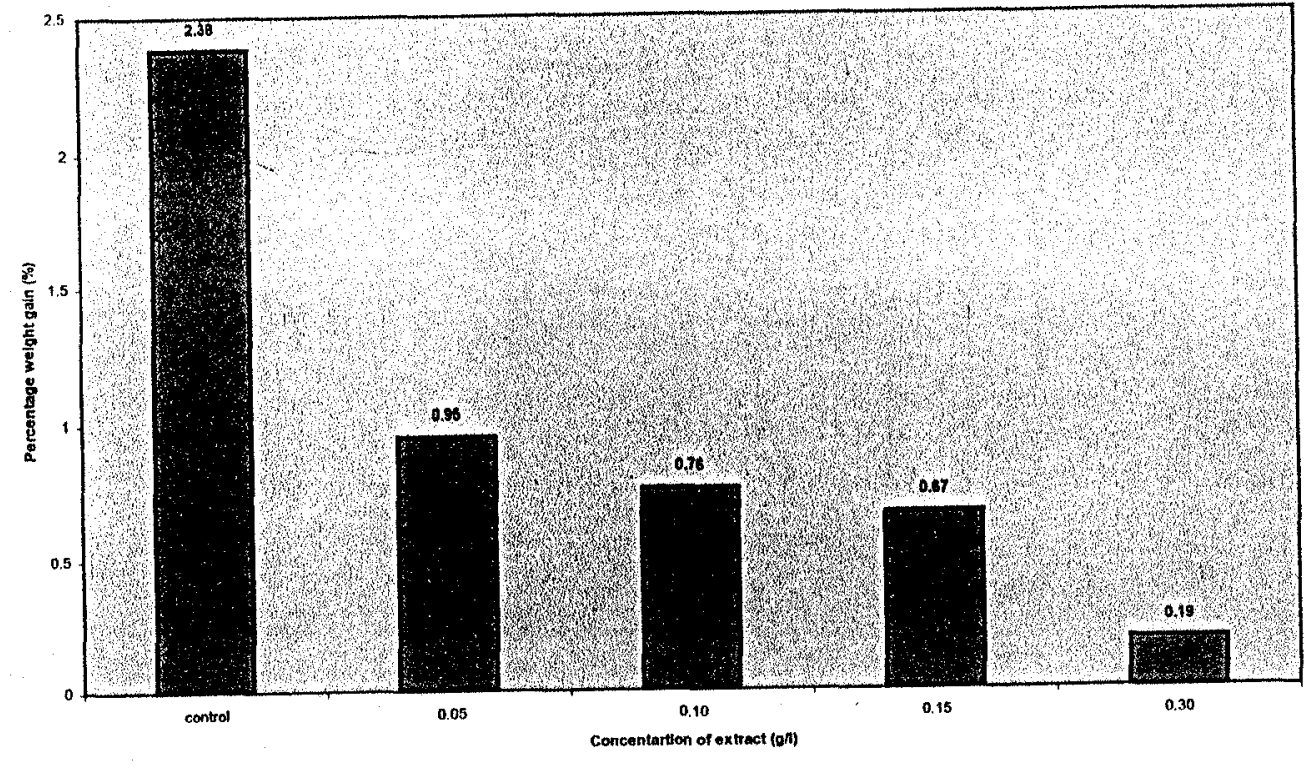

Figure 2:Percentage weight gain of Clarias gariepinus exposed to sub-lethal concentrations of tobacco leaves extract

The mean values of water quality parameters measured during sub-lethal exposure are presented in Table 2 . The slight variations observed in these values did not reveal any statistically significant difference $(p>0.05)$.

Table 2: Mcan* values of water quality parameters observed during sub-lethal exposure.

\begin{tabular}{|l|l|l|l|l|l|}
\hline \multirow{2}{*}{ Parameter } & \multicolumn{5}{|c|}{ Concentration of extract $(\mathrm{g} / \mathrm{l})$} \\
\cline { 2 - 6 } & $0.00($ control) & 0.05 & 0.10 & 0.15 & 0.30 \\
\hline Temperature $\left({ }^{\circ} \mathrm{C}\right)$ & $28.75(0.04)$ & $28.50(0.07)$ & $28.50(0.05)$ & $28.50(0.03)$ & $28.60(0.02)$ \\
\hline $\begin{array}{l}\text { Dissolved oxygen } \\
(\mathrm{mg} /)^{2}\end{array}$ & $6.50(0.30)$ & $5.30(0.20)$ & $4.50(0.15)$ & $4.30(0.05)$ & $3.50(0.10)$ \\
\hline $\begin{array}{l}\mathrm{NH}_{3^{-}} \\
\mathrm{Ammonium}(\mathrm{mg} / \mathrm{l})\end{array}$ & $3.60(0.40)$ & $3.60(0.60)$ & $1.56(0.22)$ & $1.80(0.10)$ & $1.68(0.80)$ \\
\hline $\mathrm{pH}$ & $6.31(0.03)$ & $6.33(0.15)$ & $6.19(0.20)$ & $6.12(0.04)$ & $6.25(0.85)$ \\
\hline Conductivity(us/cm) & $146.30(1.20)$ & $157.20(2.10)$ & $150.00(1.00)$ & $160.80(3.40)$ & $168.80(2.30)$ \\
\hline
\end{tabular}




\section{DISCUSSION}

The acute toxicity of tobacco leaf dust on Oreochromis niloticus has been studied (Agbon et al, 2002) and reported to have a $48 \mathrm{~h} \mathrm{LC50}$ of $109.6 \mathrm{mg} / \mathrm{l}$. This value is far lower than that estimated in this study in which $C$. gariepinus was found to have $626 \mathrm{mg} / \mathrm{l}$ thus indicating that $C$. gariepinus was more resistant to tobacco toxicity than $O$. niloticus. The toxicity of other plant extracts on fish has been reported. Onusiriuka and Ufodike (1994 and 1998) reported that when they exposed $C$. gariepimus to the bark extract of Blighia sapida and Kigelia africana they recorded $8.317 \mathrm{mg} / 1$ and $26.913 \mathrm{mg} / 1$ respectively. This observation implies that tobacco leaf dust extract is less toxic to $C$. gariepinus than $B$. sapida and $K$. africana

Mucus was observed to have accumulated on the gills of the moribund fish which might be responsible for the mortalities recorded in this study. Konar (1970) reported that accumulation of mucus on the gills reduces respiratory activity in fish. The inability of the gill surface to actively carry out gaseous exchange might be responsible for the recorded mortalities. The observed restlessness and jumping of fish in bioassay media might be due to the effect of nicotine, which is a stimulant, in tobacco leaf (Hassal, 1982). Yamamoto et al (1962) reported that this stimulant could bind on to acetylcholine receptors in the nervous system thus causing the excitation and the resultant frequent jumping and restlessness.

During the sub-lethal exposure, a decrease in weight (figure 2) gain by the fish with increase in extract concentration was observed. This observation was not unexpected as Omoregie et al (1990), had reported that sub-lethal concentrations of toxicants in aquatic environment often result in several physiological dysfunctions instead of an outright mortality of fish. The retardation of growth, as shown in figure 2 , might be due to interactions of the nicotine with normal metabolism of the fish. This finding also agrees with the report of Onusiriuka and Ufodike (1998) on C. gariepinus and Omoregie et al (1998) on Oreochromis niloticus when working with different plant-derived piscicides. The water quality parameters in the different treatments showed no significant difference hence the effects on this study could be negligible.

The statistically significant $\quad(p<0.05)$ decrease in values of the haematological parameters (Table 1) studied was not uncommon in fish exposed to sub-lethal concentrations of toxicants. Similar reduction of haematological indices was reported by Musa and Omoregie (1999) when C. gariepinus was treated with sub-lethal doses of malachite green. Omoregie et al (1994) had earlier reported similar observations when they subjected $O$. niloticus to sublethal concentrations of formalin. The reduction in these blood parameters is an indication of anaemia caused by exposure to the extract of tobacco leaf dust. This anaemic response could be as a result of destruction of erythrocyte or inhibition of erythrocyte production (Wintrobe, 1978) or haemodilution as reported by Sampath et al (1993).

Conclusion: This study confirms that the extract of tobacco leaf exerts piscicidal property, an encouraging information for tobacco growers/farmers in view of their worries over anti-smoking campaign by the medical regulations. This study has shown that tobacco leaf dust extract can be applied in pond management to eradicate stunted and unwanted fish populations so as to enhance production of desirable fish species for the country.

ACKNOWLEDGEMENT: The authors are grateful to the Department of Aquaculture and Fisheries Management, University of Agriculture, Abeokuta, Nigeria for providing the facilities used in this study.

\section{REFERENCES}

Agbon, A.O., Omoniyi, I.T. and Teko, A.A (2002). Acute toxicity of tobacco (Nicotiana tobaccum) leaf dust on Oreochromis niloticus and haematological changes resulting from sublethal exposure. Journal of Aquatic Sciences 17(1): 5 8.

Al-Jedah, J.H., Ali, M.Z. and Robinson, R.K. (1999). The nutritional importance to local communities of fish caught off the coast of Qatar. Nutrition and Food Science. 6:288 - 294.

Blaxhall, P.C. (1972). The haematological assessment of the health of freshwater fish. J. fish. Biol.; 4:593 604.

Blaxhall, P.C. and Daisley, K.W. (1973). Routine haematological methods for use with fish blood. J. Fish Biol; 5:771 - 781.

Buikema, A.L.; Niedertehner, R.R. and Cairns, J. (1982). Biological monitoring Part IV. Toxicity testing. Water Resources, 16;239-262.

Egan, H., Kirk, S.R. and Sawyer, R. (1981). Pearson's Chemical analysis of food, $8^{\text {th }}$ Ed. Churchill Livingstone, London.

Hassal, K.A. (1982). The Chemistry of Pesticides. Macmillan press, London. $372 \mathrm{pp}$.

Konar, S.K. (1970). Nicotine as a fish poison. Progressive Fish Culturist. 32:103-104 
Mason,C.F. (1998). Biology of Freshwater Pollution, Third edition, Longman, England.356pp.

Musa, S.O. and Omoregie, E. (1999). Haematological changes in the mudfish, Clarias gariepinus (Burchell) exposed to malachite green.Journal of Aquatic Sciences, 14:37-42.

Omoniyi, I.T. (1995). Hybridization in Oreochromis niloticus (Trewavas) and Sarotherodon galilaeus (Linnaeus), an assessment of morphometrics and the response of the FI fry to formulated diets. Ph.D Thesis, University of Ibadan, Ibadan Nigeria. $262 \mathrm{pp}$.

Omoregic, E.; Ufodike, E.B.C. and Keke, I.R. (1990). Tissue chemistry of Oreochromis niloticus cxposed to sub-lethal concentrations of Gatmmalin 20 and $\Lambda$ ctcllic $25 E \mathrm{EC}$. Journal of Aquatic Sciences, 5:33-36.

Omoregie, E., Eseyin, T.G. and Ofojekwu, P.C.(1994). Chronic effects of formalin on erythrocyte counts and plasma glucose of the Nile Tilapia, Oreochromis niloticus. Asian Fisheries Science 7:1-6.

Omoregie, E. (1998). Changes in haematology of the Nile Tilapia, Oreochromis niloticus (Trewavas) under the effect of crude oil. Acta Hydrobiologica, 40:284 - 292.

Omoregie, E; Eseyin, T.G. and Ofojekwu, P.C. and Amali, E.i. (1998). Effects of sub-lethal concentrations of formalin on weight gain in Nile tilapia, Oreochromis niloticus (Trewavas). Asian Fisheries Sciences, 10: 323-327.

Onusiriuka, B.C. and ufodike E.B.C. (1994). Acute toxicity of water extracts of Akee apple, Blighia sapida and sausage plant, Kigelia africana on
African catfish, Clarias gariepinus (Teugals) Journal of Aquatic Sciences, 9:35-41.

(1998). Growth of African catfish, Clarias garicpinus (Teugals) subjected to sub-lethal concentrations of water extract of Akee apple, Blighia sapida and sausage plant, Kigelia africana. Journal of Aquatic Sciences, 13:59- 62.

Otubusin, S.O. (1999). Fish for Thought. COLERM Seminar Series 4. University of Agriculture Abeokuta. $15 \mathrm{p}$.

Reed, W; Burchard, J. Hopson, A.J. Jenness, J. and Yaro, 1. (1967). Fish and Fisheries of Northern Nigeria. Gaskiya Corporation, Zaria, Nigeria 226 $\mathrm{pp}$.

Sampath, K; Velamnial, S; Kennedy, I.J; and James R. (1993). Haematological changes and their recovery in Orcochromis mossambicus as a function of exposure period and sub-lethal levels of Ekalus. Acta Hydrobiologica, $35: 73-83$.

Smit, G.L; Hattingh, J. and Burger, A.P. (1979). Haematological assessment of the effects of anaesthetic MS 222 in natural and neutralized form in three freshwater fish species, interspecies differences. J. Fish Biol; 15: 633-643.

Wardlaw, A.C. (1985). Practical Statistics for Experimental Biologists. John Wiley \& Sons. New York 290 pp.

Wintrobe, M.M. (1978). Clinical Haematology. H. Kimpton, London, U.K. 488pp.

Yamamoto, I., Kamimura, H; Yamamoto, P; Sakai, S. and Goda M. (1962). Agric. Biol. Chem., 26: 709. 